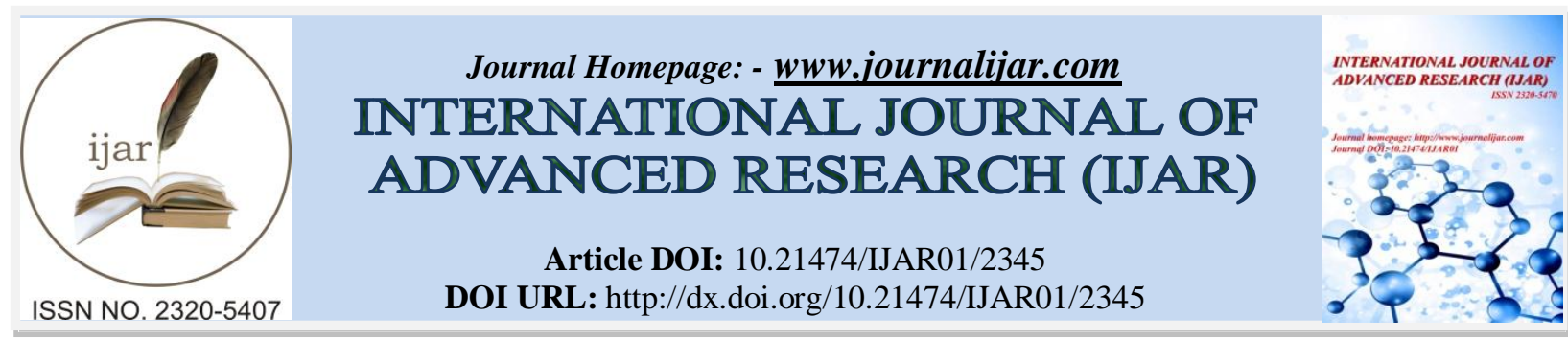

RESEARCH ARTICLE

\title{
A COMPARATIVE ANALYSIS OF JOB SATISFACTION AMONG MALE \& FEMALE FACULTY MEMBERS IN SELF-FINANCED COLLEGES OF WESTERN UTTAR PRADESH.
}

\author{
Megha Rastogi $^{1}$, Dr. Manish Srivastava ${ }^{2}$ and Dr. Chanchal Chawla ${ }^{3}$. \\ 1. Research Scholar, TMIMT, TMU Moradabad. \\ 2. Professor, Kaziranga University, Jorhat, Assam. \\ 3. Assistant Professor, TMIMT, TMU, Moradabad.
}

\section{Manuscript Info}

Manuscript History

Received: 30 September 2016

Final Accepted: 30 October 2016

Published: November 2016

Key words:-

Job satisfaction, Internal factors, external factors, personal factors.

\section{Abstract}

Job satisfaction is a topic of intense research since the emergence of organizational studies. Though lots of research has been done on the topic of Job satisfaction in different parts of the world but hardly any research has been done on faculty job satisfaction in Western part of Uttar Pradesh. The main objective of this study was to ascertain job satisfaction level of male and female faculty members in self financed colleges of Western Uttar Pradesh. To achieve this objective various factors were taken into consideration they were passion for teaching, Joy for teaching, Job commitment, Punctuality and regularity, Peace of mind and Feel good for the services to the society. A survey was conducted for this study and a questionnaire designed on five point likert scale was used to collect the data from 385 faculty members of twenty two private colleges of Western UP. The data was analyzed through SPSS version 19 by applying various statistical tools of descriptive statistics and one way ANOVA . The findings of the study showed that there is no significant difference in the job satisfaction level of male and female faculty members of these colleges, both of them were equally satisfied on different factors which were taken into consideration.

Copy Right, IJAR, 2016,. All rights reserved.

\section{Introduction:-}

The development of any nation depends upon the development of its citizens and the development of citizens depends on its education system and the whole education system depends on the quality of teachers it has. When the nation have intelligent, multitalented, mentally and physically strong and balanced, socially and culturally developed teachers than that nation will have intelligent, versatile and smart citizens. Therefore, it can be said that teachers play the most crucial role in the development of any nation and they are the foundation stone of successful education system. But any education system can be successful only when teachers are satisfied with their job. Thus, job satisfaction of teachers play a very important role in the development of any nation by developing students in all the fields.

The term job satisfaction is a very complicated term. There is a lack of adequate definition and satisfactory theory about its meaning. (Herzberg et al. 1957). The difference in views on job satisfaction exist because of number of 
reason- firstly by the various nature of jobs that individuals perform; secondly the attempt to conceptualize job satisfaction in a variety of ways by different disciplines like Psychology, Sociology, Education and Management etc, and finally, the variety of methods employed by various researchers to study job satisfaction. But at last, it is widely accepted as psychological aspect of effective functioning in any profession. The credit of this thought goes to Hoppock (1935) who views Job satisfaction as a combination of psychological, physiological and environmental circumstances that cause a person truthfully to say, "I am satisfied with my job". Thus job satisfaction is a favorableness with which employees views their work.

It can be said that it is an attitude which people hold towards their jobs, positive attitude towards the job signifies satisfaction with it and negative attitudes towards it signifies dissatisfaction with it. Thus, job satisfaction is the end state in feeling, accompanying the attainment by an impulse of its objective.

Moreover, there was disagreement among researchers whether Job satisfaction is a single dimension or multiple dimensions. Researchers like Porter and Lawler (1972) define Job satisfaction as a one-dimensional contract; that is, one is generally satisfied or dissatisfied with one's job. In contrast, Smith, Kendall and Hulin argue that Job satisfaction is multidimensional; that is one may be more or less satisfied with one's supervisor, pay or workplace etc.

There are different views on factors affecting job satisfaction. Some considered factors affecting job satisfaction are internal only, some considered external only whereas some considered personal only. But according to Telman and Unsal (2004) factors affecting job satisfaction are internal, external and personal. Internal factors include characteristics related to the basic nature of work. External factors are the conditions such as physical work, promotion conditions, relationships with superiors and co-workers, creativity, job security, organizational structure and culture. Personal factors include factors such as demographic characteristics (gender, age, length of service, educational level etc.), personality traits and incentive, knowledge and skills. Furthermore, according to (Grunwald \& Peterson, 2003; Hagedorn, 2000; Zhou \& Volkwein, 2004) job satisfaction of academic members in higher educational institutions is also affected by the institutional variables, including leadership, collegial and student relationship, climate and culture of the university

It shows that there are large numbers of factors which affect the job satisfaction of people working in different field or same field, in different environment or same environment. But at the same time it should be kept in mind that all factors affect differently to all individuals. Moreover, growth and health of educational institutions depend upon the job satisfaction of its faculty members (Chen et al., 2006) and quality in teaching and learning can only be enhanced if faculty members are satisfied and content (Wood, 1976) .

The goals of higher education are to provide in-depth knowledge, seek academic development, educate students, and to coordinate national development demands (Johnes \& Taylor, 1990) cannot be accomplished efficiently when teachers are not satisfied with their job. Therefore, Syed et al., (2012) recognized that faculty satisfaction is the most significant aspect in higher education and is important for the improvement, efficacy and effectiveness of the upper education system.

\section{Literature Review:-}

\section{Study of satisfaction of faculty members or teachers and their gender:-}

A large amount of research has been done by the researchers on various dimension of job satisfaction of faculty members and their gender. Few studies are as follow-

Meenu Srivastava and Dolly Mogra (2015) conducted a study in Udaipur city, Rajasthan on male and female faculty members of higher educational institutions to analyze their job satisfaction level. The result of the revealed that majority of faculty members had moderate level of job satisfaction. Their job satisfaction is influenced by peer relationship, working environment and administrative factors. It also showed that Job satisfaction level of male and female faculty members of these institutions was also different. Female faculty members were found to be more satisfied as compared to male faculty members.

Nisamuddin.T. (2013) conducted a study on faculty members of Kerela Colleges to analyse their job satisfaction level, difference between male and female job satisfaction level and relationship between years of service and job satisfaction. The result of the study revealed that nature of job, rules and regulations, financial aspect, students' 
behaviour, classroom activities, behaviour and attitude of superior, subordinate, non-teaching staff, administrative authorities, freedom for participating in decision making, recognition of the society, etc play a very important role in influencing job satisfaction level of faculty members. It also reveals that there exists difference in male and female job satisfaction level too. Female faculty members were more satisfied as compared to male faculty members. Moreover, it shows existence of positive relationship between years of service and job satisfaction level, which means as the years of service increases job satisfaction also increases and vice-versa.

Santosh kumar and Manoj Baviskar(2012) conducted a study on faculty members of North East Maharastra campus to analayse their job satisfaction level, to find out difference between male and female job satisfaction level and to find out difference between permanent and contract basis faculty members job satisfaction level. The result of the study revealed that all the faculty members were highly satisfied with their job, there is no difference between male and female job satisfaction level as well as there is no difference in the job satisfaction level of permanent and contract basis faulty members.

K.Leelavathy (2012) conducted a study in self financing engineering colleges of Chennai to analyse job satisfaction level of female faculty members. The result of the study revealed that job satisfaction of female faculty members is positively associated with teacher student relationship, role change, job involvement whereas it is negatively associated with salary, discipline and work environment.

\section{Study of satisfaction of faculty members or teachers and the type of employer, i.e. public sector and private sector:-}

Anil k. Bhatt and Thomas Remigius (2015) conducted a comparative study on selected MBA public and private college teachers of South Rajasthan to analyze their job satisfaction level. The result of the study revealed that there exist a significant difference in the job satisfaction level of the private and public sector management teachers on various dimensions of physical teaching condition, flexible working hours, job security and reward system. Moreover, public sector teachers were found to be more satisfied as compared to private management teachers.

Jaspreet Kaur, Shivani Miglani, Rajesh Kumar (2014) conducted a comparative study on faculty members of Government and private colleges of Ludhiana to analyze their job satisfaction level and to find out various factors affecting their job satisfaction. The result of the study revealed that there exist positive relationships between all the factors taken by researchers for their study and job satisfaction level. It means when salary, recognition for good result, opportunity for personal growth, autonomy, grievance handling, participation in decision making improves job satisfaction also improves and vice versa. At the same time, it shows that there is no significant difference between job satisfaction level of private and government college teachers.

Datta B. Pawase (2013) conducted a study on faculty members working in government and private polytechnic colleges of Dhule city of Rajasthan to assess how job satisfaction level influences their performance. The result of the study revealed that performance of faculty members in both private and government colleges depends upon different aspects of job rather than on job satisfaction. At the same time it also reveals that there exist a significant difference between government and private polytechnics faculty members on the dimensions of promotion, respect to co-workers and communication factor.

Saraswati (2013) conducted a comparative study between government and private colleges' faculty members of Delhi to measure their job satisfaction level. The result of the study revealed that faculty members working in Government colleges of Delhi were more satisfied on all the dimensions as compared to faculty members of Private colleges in Delhi.

\section{Objective:-}

The main objective of the study is to analyze the job satisfaction among the male and female faculty members of self financed colleges of Western Uttar-Pradesh.

\section{Hypothesis:-}

To achieve its objective and after the review of literature the researcher has taken six dependent variables into consideration they are Passion for teaching, Joy for teaching, Job commitment, punctuality and regularity, Peace of mind and feel good for providing services to the society to measure job satisfaction among the faculty members of self financed colleges of Western Uttar Pradesh. For this, hypothesis is set for each dependent variable. They are 
Ho: There is no significant difference in the job satisfaction of male and female faculty members of self-colleges of Western Uttar Pradesh.

1. Ho: (a) There is no significant difference in the job satisfaction level of male and female faculty members in respect of passion for teaching.

2. Ho:(b) There is no significant difference in the job satisfaction level of male and female faculty members in respect of joy for teaching.

3. Ho: (c) There is no significant difference in the job satisfaction level of male and female faculty members in respect of job commitment.

4. Ho: (d) There is no significant difference in the job satisfaction level of male and female faculty members in respect of punctuality and Regularity.

5. Ho: (e) There is no significant difference in the job satisfaction level of male and female faculty members in respect of Peace of mind.

6. Ho:(f) There is no significant difference in the job satisfaction level of male and female faculty members in respect of feel good for providing services to the society.

\section{Research Methodology:-}

Population, Sample and who participated in the study:-

For the present research topic the entire male and female faculty members of self financed colleges of Western U.P constitute the population for study. But due to time and money constraint the researcher has taken a sample of 385 faculty members from twenty two self-financed colleges of Western Uttar Pradesh, by adopting convenience sampling method. In convenience sampling the researcher approached those faculty members who are available and approachable at the time of survey but care has been taken that those faculties should represent the entire population.

\section{Data Collection:-}

As the present research topic is descriptive in nature, the researchers have chosen survey method to collect the required data from faculty members. A self structured questionnaire designed on five point likert scale ( 5 for highly satisfied, 4 for satisfied, 3 for neither satisfied nor dissatisfied, 2 for dissatisfied and 1 for highly dissatisfied) has been used. The data is collected from 385 faculty members; consist of 189 males and 196 females from all the age group of 25-65, all designation lecturers- Professors, background and experience.

\section{Data Analysis:-}

For analysis of data, Microsoft Excel has been used. To enter data, coding option has been used at the initial stage. The researcher has analyzed data through descriptive statistics and one way ANOVA in SPSS 19. It is justified on the ground because it measures the variance of job satisfaction among the male and female faculty members of selffinanced colleges of Western U.P.

Ho:- 2(a) There is no significant difference in the job satisfaction level of male and female faculty members in respect of Passion for teaching.

Table 1:- Descriptive Statistics

Dependent Variable:Q2

\begin{tabular}{|c|c|c|c|}
\hline Gender & Mean & Std. Deviation & $\mathbf{N}$ \\
\hline 1(Male) & 1.87 & .983 & 189 \\
\hline 2(Female) & 1.62 & .886 & 196 \\
\hline Total & $\mathbf{1 . 7 4}$ & $\mathbf{. 9 4 1}$ & $\mathbf{3 8 5}$ \\
\hline
\end{tabular}


Table 2:-

Tests of Between-Subjects Effects

Dependent Variable: Q2

\begin{tabular}{|l|r|r|r|r|r|r|}
\hline Source & $\begin{array}{c}\text { Type III Sum } \\
\text { of Squares }\end{array}$ & df & Mean Square & \multicolumn{1}{c|}{ F } & \multicolumn{1}{c|}{ Sig. } & $\begin{array}{c}\text { Partial Eta } \\
\text { Squared }\end{array}$ \\
\hline Corrected Model & $3.726 \mathrm{a}$ & 1 & 3.726 & 4.270 & .040 & .018 \\
Intercept & 697.665 & 1 & 697.665 & 799.552 & .000 & .779 \\
Gender & 3.726 & 1 & 3.726 & 4.270 & .040 & .018 \\
Error & 198.073 & 383 & .873 & & & \\
Total & 897.000 & 385 & & & & \\
Corrected Total & 201.799 & 384 & & & & \\
\hline
\end{tabular}

a. R Squared $=.018($ Adjusted R Squared $=.014)$

\section{Interpretation:-}

Table 1 of descriptive statistics shows the mean of passion for teaching 1.87 for male and 1.62 for female faculty members with 0.983 and 0.886 standard deviations in their values respectively. Table 2, Analysis of Variance test suggests the factor value of 4.270 which is not significant with the values of 0.040 . Thus it can be concluded that there is no significant difference in the job satisfaction level of male and female faculty members in respect of passion for teaching.

Moreover, Partial Eta Square value of 0.018 suggests that only $1.8 \%$ variations in the passion for teaching can be associated to gender. These findings make the researcher to accept the null hypothesis that there is no significant difference between the job satisfaction of male and female faculty members of self-financed colleges.

Ho:2(b) There is no significant difference in the job satisfaction level of male and female faculty members in respect of joy for teaching.

Table 1:- Descriptive Statistics

Dependent Variable:Q4

\begin{tabular}{|c|c|c|c|}
\hline Gender & Mean & Std. Deviation & N \\
\hline 1(Male) & 1.97 & .899 & 189 \\
\hline 2(Female) & 1.72 & .772 & 196 \\
\hline Total & $\mathbf{1 . 8 4}$ & $\mathbf{. 8 4 4}$ & $\mathbf{3 8 5}$ \\
\hline
\end{tabular}

Table 2:-

Tests of Between-Subjects Effects

Dependent Variable: Q4

\begin{tabular}{|l|r|r|r|r|r|r|}
\hline Source & $\begin{array}{r}\text { Type III Sum } \\
\text { of Squares }\end{array}$ & df & Mean Square & F & \multicolumn{1}{c|}{ Sig. } & \multicolumn{1}{c|}{$\begin{array}{c}\text { Partial Eta } \\
\text { Squared }\end{array}$} \\
\hline Corrected Model & $3.651 \mathrm{a}$ & 1 & 3.651 & 5.222 & .023 & .022 \\
Intercept & 780.192 & 1 & 780.192 & 1116.034 & .000 & .831 \\
Gender & 3.651 & 1 & 3.651 & 5.222 & .023 & .022 \\
Error & 158.690 & 383 & .699 & & & \\
Total & 940.000 & 385 & & & & \\
Corrected Total & 162.341 & 384 & & & & \\
\hline
\end{tabular}

a. R Squared $=.022$ (Adjusted R Squared $=.018$ ) 


\section{Interpretation:-}

Table 1 of descriptive statistics shows the mean for joy for teaching is 1.97 for male and 1.72 for female faculty members with 0.899 and 0.722 standard deviations in their values respectively. Table 2, Analysis of Variance test suggests the factor value of 5.222 which is not significant with the values of 0.023.It can be concluded that there is no significant difference in the job satisfaction level of male and female faculty members in respect of joy for teaching.

Moreover, Partial Eta Square value of 0.022 suggests that only $2.2 \%$ variations in the joy for teaching can be associated to gender. These findings make the researcher to accept the null hypothesis that there is no significant difference between the job satisfaction of male and female faculty members of self-financed colleges.

Ho:2 (c) There is no significant difference in the job satisfaction level of male and female faculty members in respect of job commitment.

Table 1:- Descriptive Statistics

Dependent Variable:Q43

\begin{tabular}{|c|c|c|c|}
\hline Gender & Mean & Std. Deviation & N \\
\hline 1(Male) & 1.68 & .822 & 189 \\
\hline 2(Female) & 1.82 & .823 & 196 \\
\hline Total & $\mathbf{1 . 7 5}$ & $\mathbf{. 8 2 4}$ & $\mathbf{3 8 5}$ \\
\hline
\end{tabular}

Table 2:-

\section{Tests of Between-Subjects Effects}

Dependent Variable: Q43

\begin{tabular}{|l|r|r|r|r|r|r|}
\hline Source & $\begin{array}{c}\text { Type III Sum } \\
\text { of Squares }\end{array}$ & df & Mean Square & \multicolumn{1}{c|}{ F } & \multicolumn{1}{c|}{ Sig. } & $\begin{array}{c}\text { Partial Eta } \\
\text { Squared }\end{array}$ \\
\hline Corrected Model & $1.225^{\mathrm{a}}$ & 1 & 1.225 & 1.811 & .180 & .008 \\
Intercept & 699.740 & 1 & 699.740 & 1034.209 & .000 & .820 \\
Gender & 1.225 & 1 & 1.225 & 1.811 & .180 & .008 \\
Error & 153.587 & 383 & .677 & & & \\
Total & 857.000 & 385 & & & & \\
Corrected Total & 154.812 & 384 & & & & \\
\hline
\end{tabular}

a. $\mathrm{R}$ Squared $=.008$ (Adjusted R Squared $=.004$ )

\section{Interpretation:-}

Table 1 of descriptive statistics shows the mean for job commitment is 1.68 for male and 1.82 for female faculty members with 0.822 and 0.823 standard deviations in their values respectively. Table 2, Analysis of Variance test suggests the factor value of 1.811 which is not significant with the values of 0.180.It can be concluded that there is no significant difference in the job satisfaction level of male and female faculty members in respect of job commitment

Moreover, Partial Eta Square value of 0.008 suggests that only $0.8 \%$ variations in the job commitment can be associated to gender. These findings make the researcher to accept the null hypothesis that there is no significant difference between the job satisfaction of male and female faculty members of self-financed colleges.

Ho: 2(d) There is no significant difference in the job satisfaction level of male and female faculty members in respect of punctuality and Regularity.

Table 1:- Descriptive Statistics

Dependent Variable:Q50

\begin{tabular}{|c|c|c|c|}
\hline Gender & Mean & Std. Deviation & $\mathbf{N}$ \\
\hline 1(Male) & 1.50 & .601 & 189 \\
\hline 2(Female) & 1.53 & .700 & 196 \\
\hline Total & $\mathbf{1 . 5 2}$ & $\mathbf{. 6 5 3}$ & $\mathbf{3 8 5}$ \\
\hline
\end{tabular}


Table 2:-

\section{Tests of Between-Subjects Effects}

Dependent Variable: Q50

\begin{tabular}{|l|r|r|r|r|r|r|}
\hline Source & $\begin{array}{c}\text { Type III Sum } \\
\text { of Squares }\end{array}$ & df & Mean Square & \multicolumn{1}{c|}{ F } & \multicolumn{1}{c|}{ Sig. } & $\begin{array}{c}\text { Partial Eta } \\
\text { Squared }\end{array}$ \\
\hline Corrected Model & $.084^{\mathrm{a}}$ & 1 & .084 & .197 & .657 & .001 \\
Intercept & 524.905 & 1 & 524.905 & 1226.968 & .000 & .844 \\
Gender & .084 & 1 & .084 & .197 & .657 & .001 \\
Error & 97.112 & 383 & .428 & & & \\
Total & 623.000 & 385 & & & & \\
Corrected Total & 97.197 & 384 & & & & \\
\hline
\end{tabular}

a. R Squared $=.001$ (Adjusted R Squared $=-.004$ )

\section{Interpretation:-}

Table 1 of descriptive statistics shows the mean for Punctuality and Regularity is 1.50 for male and 1.53 for female faculty members with 0.601 and 0.700 standard deviations in their values respectively. Table 2, Analysis of Variance test suggests the factor value of .197 which is not significant with the values of 0.657 . It can be concluded that there is no significant difference in the job satisfaction level of male and female faculty members in respect of Punctuality and regularity.

Moreover, Partial Eta Square value of 0.001 suggests that only $0.1 \%$ variations in the punctuality and regularity can be associated to gender. These findings make the researcher to accept the null hypothesis that there is no significant difference between the job satisfaction of male and female faculty members of self-financed colleges.

Ho: 2(e) There is no significant difference in the job satisfaction level of male and female faculty members in respect of Peace of mind.

Table 1:- Descriptive Statistics

Dependent Variable:Q74

\begin{tabular}{|c|c|c|c|}
\hline Gender & Mean & Std. Deviation & N \\
\hline 1(Male) & 2.80 & 1.077 & 189 \\
\hline 2(Female) & 2.81 & 1.101 & 196 \\
\hline Total & $\mathbf{2 . 8 1}$ & $\mathbf{1 . 0 8 7}$ & $\mathbf{3 8 5}$ \\
\hline
\end{tabular}

Table 2:-

Tests of Between-Subjects Effects

Dependent Variable: Q74

\begin{tabular}{|l|r|r|r|r|r|r|}
\hline Source & $\begin{array}{c}\text { Type III Sum } \\
\text { of Squares }\end{array}$ & df & Mean Square & \multicolumn{1}{|c|}{ F } & \multicolumn{1}{c|}{ Sig. } & $\begin{array}{r}\text { Partial Eta } \\
\text { Squared }\end{array}$ \\
\hline Corrected Model & $.008^{\mathrm{a}}$ & 1 & .008 & .007 & .935 & .000 \\
Intercept & 1803.536 & 1 & 1803.536 & 1518.906 & .000 & .870 \\
Gender & .008 & 1 & .008 & .007 & .935 & .000 \\
Error & 269.538 & 383 & 1.187 & & & \\
Total & 2075.000 & 385 & & & & \\
Corrected Total & 269.546 & 384 & & & & \\
\hline
\end{tabular}

a. R Squared $=.000$ (Adjusted R Squared $=-.004$ )

\section{Interpretation:-}

Table 1 of descriptive statistics shows the mean for peace of mind is 2.80 for male and 2.81 for female faculty members with 1.077 and 1.101 standard deviations in their values respectively.Table 2, Analysis of Variance test suggests the factor value of 0.007 which is not significant with the values of 0.935 .It can be concluded that there is 
no significant difference in the job satisfaction level of male and female faculty members in respect of Peace of Mind.

Moreover, Partial Eta Square value of 0.000 suggests that only $0 \%$ variations in the Peace of mind can be associated to gender. These findings make the researcher to accept the null hypothesis that there is no significant difference between the job satisfaction of male and female faculty members of self-financed colleges.

Ho:2(f) There is no significant difference in the job satisfaction level of male and female faculty members in respect of Feel good for providing services to the society.

Table 1:- Descriptive Statistics.

Dependent Variable:Q78

\begin{tabular}{|c|c|c|c|}
\hline Gender & Mean & Std. Deviation & N \\
\hline 1(Male) & 1.71 & .693 & 189 \\
\hline 2(Female) & 1.78 & .730 & 196 \\
\hline Total & $\mathbf{1 . 7 5}$ & $\mathbf{. 7 1 1}$ & $\mathbf{3 8 5}$ \\
\hline
\end{tabular}

Table 2:-

Tests of Between-Subjects Effects

Dependent Variable: Q78

\begin{tabular}{|l|r|r|r|r|r|r|}
\hline Source & $\begin{array}{c}\text { Type III Sum } \\
\text { of Squares }\end{array}$ & df & Mean Square & \multicolumn{1}{c|}{ F } & \multicolumn{1}{c|}{ Sig. } & $\begin{array}{c}\text { Partial Eta } \\
\text { Squared }\end{array}$ \\
\hline Corrected Model & $.264^{\mathrm{a}}$ & 1 & .264 & .521 & .471 & .002 \\
Intercept & 697.207 & 1 & 697.207 & 1375.677 & .000 & .858 \\
Gender & .264 & 1 & .264 & .521 & .471 & .002 \\
Error & 115.046 & 383 & .507 & & & \\
Total & 814.000 & 385 & & & & \\
Corrected Total & 115.310 & 384 & & & & \\
\hline
\end{tabular}

a. R Squared $=.002$ (Adjusted R Squared $=-.002$ )

\section{Interpretation: -}

Table 1 of descriptive statistics shows the mean for Feel good for the services to the society is 1.71 for male and 1.78 for female faculty members with .693 and .730 standard deviations in their values respectively. Table 2 , Analysis of Variance test suggests the factor value of 0.521 which is not significant with the values of 0.471. It can be concluded that there is no significant difference in the job satisfaction level of male and female faculty members in respect of Feel-good for the service to society

Moreover, Partial Eta Square value of .002 suggests that only 0.2\% variations in the feel good for the services to the society can be associated to gender. These findings make the researcher to accept the null hypothesis that there is no significant difference between the job satisfaction of male and female faculty members of self-financed colleges.

\section{Conclusion:-}

On the basis of data analysis it can be concluded that null hypothesis is accepted as there is no significant difference in the job satisfaction of male and female faculty members of self-financed colleges of Western Uttar Pradesh on various dimensions of passion for teaching, joy for teaching, job commitment, punctuality and regularity, peace of mind and feel good for services to the society.

\section{Limitations of the Study:-}

The study has the following limitations-

1. The sample of faculty members is drawn from one part of one state; therefore, results may not be generalized able to all states.

2. Many variables are outside the control of researcher could impact the information collected.

3. Due to time and money constraint size of the faculty members is small. 


\section{References:-}

1. Bhatt, A. and Remigius, T. (2015). A comparative study of Job satisfaction among Management teachers of MBA colleges in South Rajasthan. Management,10(1),17-33.

2. Chen, S.H., Yang, C.C., Shiau, J.Y., \& Wang, H.H. (2006). The development of an employee satisfaction model for higher education. TQM Magazine, 1(5), 484-500.

3. Datta. B. P. (2013). Role of Job satisfaction on job performance of teachers from Government and private polytechnics. International Journal of modern Engineering Research, 3(3),1561-1565.

4. Grunwald, H., \& Peterson, M.W. (2003). Factors that promote faculty involvement in and satisfaction with institutional and classroom student assessment. Research in Higher Education, 44, 173-204.

5. Herzberg, F., Mausner, b., Peterson, R.O. and Capell, D.F. (1957). Job Attitudes: Review of Research and opinion, psychological services of Pittsburg, Pittsburg.

6. Hoppock, R.(1935). Job Satisfaction. New York: Harper and Bros.

7. Hagedorn, L.S. (2000). Conceptualizing faculty job satisfaction: Components, theories, and outcomes. New Directions for Institutional Research, 105, 5-20.

8. Johnes, J., \& Taylor, J. (1990). Performance Indicators in Higher Education: Buckingham, SHRE and Open University Press

9. Kaur, J., Miglani, S., and kumar, R. (2014). Factors affecting job satisfaction of college lecturers in LudhianaAn empirical study. International journal of research and development -A management review. 3(4), 33-37.

10. Khirade, S. K.and Baviskar, M.S.(2012). Job satisfaction among the North Maharastra University teachers. Golden ResearchThought.2(2).1-4.

11. Leelavathy, K. (2012). Job satisfaction of women teachers. Abhinav, National monthly refereed journal of research in Arts \& Education. 1(12), 6-15.

12. Nizamuddin, T. (2013). Job satisfaction among college teachers: A study on Government colleges in Kerela. Asian Journal of Marketing and management Research. 2(6). 33-41

13. Saraswati. (2013). A study to measure job satisfaction level amongst lecturers of Government and private colleges in Delhi. International Journal of Research and Development in the Technology and Management Sciences, 20(6), 56-73.

14. Smith,P.C.,Kendall,L.M.,\&Hulin,C.L. (1969) The measurement of satisfaction in work and retirement. Chicago: Rand McNally.

15. Srivastava, M. and Mogra, D. (2015). Job satisfaction among teaching faculty with reference to gender. Asian Journal of Management Science, 3(10), 25-29.

16. Syed, A.A.S.G., Bhatti, N., Michael. S., Shaikh, F.M., \& Shah, H. (2012). Job satisfaction of faculty members of university in Pakistan: A case study of university of Sindh Jamshoro. Modern Applied Science, 6 (7), 89-95.

17. Telman, N., \& Unsal, P. ( 2004). Calisan Memnuniyeti. Epsilon Publishing, Istanbul.

18. Wood, O. R. (1976). A research project: Measuring job satisfaction of the community college staff. Community College Review, 3(3), 56-64.

19. Zhou, Y. \& Volkwein, J. F. (2004). Examining the influences on faculty departure intentions: A comparison of tenured versus non-tentured faculty at research universities using NSOPF-99. Research in Higher Education, 45, 139-176. 